Teka Kom. Politol. Stos. Międzynar. - OL PAN, 2016, 11/2, 65-80

\title{
KONTYNUACJA PROCESU ROZSZERZENIA JAKO WYZWANIE DLA UNII EUROPEJSKIEJ
}

\author{
Tomasz Kubin \\ Instytut Nauk Politycznych i Dziennikarstwa, Uniwersytet Śląski w Katowicach \\ e-mail: tomasz.kubin@us.edu.pl
}

\begin{abstract}
Streszczenie: Proces integracji, podjęty w Europie Zachodniej po II wojnie światowej, okazał się sukcesem. Kolejne państwa dołączały do Wspólnot Europejskich (WE), a potem do Unii Europejskiej (UE), zaś polityka rozszerzenia WE/UE stała się jednym z najistotniejszych obszarów aktywności tych organizacji międzynarodowych.

Celem artykułu jest identyfikacja i krótka analiza wybranych aspektów, głównie teoretycznych, związanych z kontynuacją rozszerzania UE i stanowiących najistotniejsze czynniki wpływające na dalszy przebieg tego procesu. Główną tezą opracowania jest stwierdzenie, że kontynuacja rozszerzania UE będzie wyglądać wyraźnie inaczej niż do tej pory i będzie procesem trudnym i długotrwałym. Problemem badawczym jest identyfikacja przyczyn takiej zmiany w charakterze procesu rozszerzania UE, który przecież do tej pory generalnie oceniany jest jako jedna z najskuteczniejszych polityk WE/UE. W tym celu zostaną przywołane funkcjonujące w literaturze przedmiotu teoretyczne modele wyjaśniania rozszerzania WE/UE i wskazane czynniki o charakterze „praktycznym”, które na rozszerzenie mają wpływ.

Aby lepiej zrozumieć obecne uwarunkowania kontynuowania rozszerzenia UE, przedstawiono także stan stosunków UE z potencjalnymi nowymi państwami członkowskimi, wybrane dane o charakterze społeczno-gospodarczym tych państw oraz nastawienie opinii publicznej w UE i w niektórych państwach kandydujących do UE. W pierwszej części wskazano formalne warunki, jakie musi spełnić państwo chcące przystąpić do Unii. Podsumowanie zawiera najistotniejsze wnioski.
\end{abstract}

Słowa kluczowe: polityka rozszerzenia Unii Europejskiej, Unia Europejska

\section{WSTĘP}

Proces politycznej i gospodarczej integracji, podjęty po II wojnie światowej w Europie Zachodniej, już po kilku latach od utworzenia trzech Wspólnot Europejskich (WE): EWWiS, EWG i EWEA(WE), okazał się sukcesem. Dynamiczny rozwój gospodarczy i szybki wzrost dobrobytu, z jakim mieliśmy do czynienia w państwach ,szóstki” w latach 50. i 60. XX wieku oraz polityczne i gospodarcze następstwa pozostawania poza głównym nurtem współpracy i integracji 
spowodowały, że kolejne państwa podjęły działania mające na celu dołączenie do Wspólnot. W traktatach założycielskich WE przewidziano możliwość przyjęcia nowych członków, a polityka rozszerzenia WE (później Unii Europejskiej - UE) stała się jednym z najistotniejszych obszarów aktywności tych organizacji międzynarodowych. Przyjmowanie nowych państw generalnie oceniane jest również jako jedna z najskuteczniejszych polityk UE (WE), zwłaszcza w sferze oddziaływania na bezpośrednie otoczenie Unii, przyczyniająca się do wzrostu poziomu bezpieczeństwa i stabilności.

Po siedmiu turach rozszerzenia od 2013 roku do UE należy 28 państw, ale proces przyjmowania nowych członków nie jest zakończony. Z czterema państwami trwają negocjacje akcesyjne, a kilka innych państw znajduje się na różnych etapach procesu, który może doprowadzić do członkostwa w UE.

Przyjmowanie nowych państw wiąże się z bardzo doniosłymi konsekwencjami nie tylko dla państw przystępujących do UE, ale także dla samej Unii. Główną tezą opracowania jest stwierdzenie, że kontynuacja rozszerzania UE będzie wyglądać wyraźnie inaczej niż do tej pory i będzie procesem trudnym i długotrwałym. Problemem badawczym jest identyfikacja przyczyn takiej zmiany w charakterze procesu rozszerzania UE, który, jak wskazano, jak do tej pory generalnie oceniany jest pozytywnie. Celem niniejszego opracowania jest zatem wskazanie i krótka analiza wybranych aspektów - przede wszystkim o charakterze teoretycznym i ogólnym, tzn. niedotyczącym konkretnych państw kandydujących do UE - związanych z kontynuacją procesu rozszerzenia Unii i stanowiących najistotniejsze czynniki wpływające na dalszy przebieg tego procesu. Przywołane zostaną funkcjonujące w literaturze przedmiotu teoretyczne modele wyjaśniania rozszerzania UE (WE) i wskazane czynniki o charakterze „,praktycznym”, które na rozszerzenie mają wpływ. Pozwoli to sformułować możliwe odpowiedzi na tak podstawowe z perspektywy wyjaśniania rozszerzenia UE (WE) pytania, jak m.in.: Dlaczego UE (WE) się rozszerza? Co wpływa na przebieg tego procesu? Jakie są następstwa rozszerzenia? Aby lepiej zrozumieć obecne uwarunkowania kontynuowania rozszerzenia UE, bardzo istotne w kontekście postawionej tezy, w odpowiednich tabelach przedstawiono stan stosunków UE z potencjalnymi nowymi państwami członkowskimi (pozwala to pokazać tempo osiągania kolejnych etapów integracji z UE poszczególnych państw), wybrane dane o charakterze społeczno-gospodarczym (które wpływają m.in. na możliwość spełnienia warunków akcesji czy finansowe obciążenie UE związane z przyjęciem nowych członków) oraz nastawienie opinii publicznej w UE i niektórych państwach kandydujących do rozszerzenia UE (co bez wątpienia ma wpływ na decyzje i działania lub zaniechania polityków i instytucji politycznych mających wpływ na proces rozszerzenia UE, zarówno w państwach członkowskich UE, jak i kandydujących).

Dla zarysowania kontekstu prawno-politycznego dotyczącego procesu rozszerzenia UE w pierwszej części artykułu przedstawione zostaną formalne warunki, jakie musi spełnić państwo chcące przystąpić do Unii. W podsumowaniu zawarto najistotniejsze wnioski. 


\section{WARUNKI ROZSZERZANIA UNII EUROPEJSKIEJ}

Podstawę prawną rozszerzenia UE stanowi obecnie art. 49 Traktatu o UE (TUE). Zgodnie z jego treścią, „każde państwo europejskie, które szanuje wartości, o których mowa w artykule 2, i zobowiązuje się je wspierać, może złożyć wniosek o członkostwo w Unii”. Wartości, o których mowa w art. 2 TUE, to „poszanowanie godności osoby ludzkiej, wolność, demokracja, równość, państwo prawne jak również poszanowanie praw człowieka, w tym praw osób należących do mniejszości. Wartości te są wspólne państwom członkowskim w społeczeństwie opartym na pluralizmie, niedyskryminacji, tolerancji, sprawiedliwości, solidarności oraz równości kobiet i mężczyzn”. Zgodnie z art. 49 TUE, o wniosku akcesyjnym ,,informuje się Parlament Europejski i parlamenty narodowe. Państwo ubiegające się o członkostwo kieruje swój wniosek do Rady, która stanowi jednomyślnie po zasięgnięciu opinii Komisji oraz po otrzymaniu zgody Parlamentu Europejskiego, udzielonej większością głosów jego członków. Brane są pod uwagę kryteria kwalifikacji uzgodnione przez Radę Europejską. Warunki przyjęcia i wynikające $\mathrm{z}$ tego przyjęcia dostosowania w traktatach stanowiących podstawę Unii są przedmiotem umowy między państwami członkowskimi a państwem ubiegającym się o członkostwo. Umowa ta podlega ratyfikacji przez wszystkie umawiające się państwa, zgodnie z ich odpowiednimi wymogami konstytucyjnymi" [Traktat o Unii Europejskiej 2010].

Wspomniane w art. 49 TUE kryteria to tzw. kryteria kopenhaskie, uzgodnione przez Radę Europejską w czerwcu 1993 roku. Należą do nich: „stabilność instytucji gwarantujących demokrację, rządy prawa, przestrzeganie praw człowieka oraz poszanowanie i ochrona mniejszości narodowych”, ,funkcjonowanie gospodarki rynkowej i istnienie potencjału mogącego sprostać konkurencji i siłom rynkowym Unii” oraz ,zdolności sprostaniu zobowiązaniom wynikającym z członkostwa, w tym podzielaniu celów unii politycznej, gospodarczej i walutowej”. Oprócz tego sformułowany został warunek dotyczący samej UE, zgodnie z którym każde nowe członkostwo będzie uzależnione od zdolności Unii do przyjęcia nowych członków, ,gdyż utrzymanie tempa integracji europejskiej leży zarówno w interesie UE, jak i kraju kandydującego" [European Council 1993].

Należy dodać, że obok warunków przyjętych w Kopenhadze w 1993 roku, w konkluzjach z kolejnych posiedzeń Rady Europejskiej regularnie pojawiała się jeszcze kwestia dotycząca wzmocnienia struktur administracyjnych i wymiaru sprawiedliwości w państwach kandydujących. W konkluzjach ze spotkania Rady Europejskiej w Madrycie w 1995 roku stwierdzono, że strategia przedczłonkowska ma pozwolić na stworzenie warunków do stopniowej, harmonijnej integracji państw kandydujących poza tym, o czym jest mowa w ramach kryteriów kopenhaskich, m.in. także poprzez „dostosowanie struktur administracyjnych” w państwach kandydujących [European Council 1995]. O tym wzmocnieniu struktur administracyjnych i wymiaru sprawiedliwości w państwach kandydujących do UE przypominano także np. w konkluzjach spotkań Rady Europejskiej w Santa Maria de Feira [Eu- 
ropean Council 2000a], Nicei [European Council 2000b] czy Göteborgu [European Council 2001a]. Rada Europejska zebrana w Laeken w grudniu 2001 roku zwróciła się do Komisji Europejskiej o przygotowanie raportu na temat wdrażania działań mających na celu wzmocnienie struktur administracyjnych i wymiaru sprawiedliwości w krajach aspirujących do UE [European Council 2001b]. Raport ten przyjęto na spotkaniu Rady Europejskiej w Sewilli w czerwcu 2002 roku, w konkluzjach którego po raz kolejny poruszono tę kwestię [European Council 2002].

Natomiast w konkluzjach ze spotkania Rady Europejskiej w Helsinkach w grudniu 1999 roku w kontekście przywołanych kryteriów kopenhaskich podkreślono znaczenie ,,pokojowego rozstrzyganie sporów” zgodnie z Kartą Narodów Zjednoczonych oraz wezwano państwa kandydujące do rozwiązania toczących się sporów granicznych z ich udziałem [European Council 1999].

Należy w tym miejscu zwrócić jeszcze uwagę na dwie kwestie. Po pierwsze, negocjacje dotyczące przystąpienia jakiegoś państwa do UE nie mają charakteru negocjacji dwóch równorzędnych stron. Państwo kandydujące musi spełnić warunki stawiane przez UE i wymogi acquis communautaire, a w istocie tym, co podlega negocjacjom, jest czas, w jakim to się stanie (liczba i długość tzw. okresów przejściowych) oraz pewne trwałe wyłączenia. Jak pisze w tym kontekście np. Wojciech Sadurski, UE może stawiać warunki, gdyż to kandydaci są bardziej zainteresowani uzyskaniem członkostwa niż UE rozszerzeniem [Sadurski 2012, 202]. Po drugie, nawet w momencie rozpoczynania negocjacji akcesyjnych (a tym bardziej na wcześniejszych etapach współpracy danego państwa z UE) nie jest przesądzone to, że cały proces akcesji zakończy się pozytywnie, tzn. przyjęciem danego państwa do Unii [Szymański 2012, 39]. Taka sytuacja jest oczywiście korzystniejsza dla UE, która zachowuje większą swobodę w swojej polityce rozszerzenia, natomiast państwo kandydujące nie ma pewności, czy podejmowane reformy nie są wprowadzane „na darmo”.

\section{ROZSZERZANIE WE/UE - MODELE TEORETYCZNE I PRAKTYKA}

Teorie wyjaśniające rozszerzania WE/UE próbują odpowiedzieć na cztery podstawowe pytania: 1) dlaczego UE się rozszerza, 2) jakie skutki wywiera UE na politykę wewnętrzną państw kandydujących, 3) jak nowe państwa członkowskie wpływają na UE, 4) jak skutki rozszerzenia wpływają na podział korzyści i kosztów pomiędzy szczególnie państwa członkowskie [Schneider 2009, 38]. Wyjaśniając kwestię rozszerzenia WE/UE, można poddać analizie trzy główne podmioty, którymi są: państwa kandydujące, państwa członkowskie oraz UE jako organizacja międzynarodowa, tzn. jej instytucje, ich aktywność dotycząca procesu rozszerzenia czy związane z nim regulacje prawne. Oprócz tego, wpływ na proces rozszerzenia ma także otoczenie zewnętrzne, tzn. polityka innych państw czy organizacji międzynarodowych, procesy i zdarzenia w środowisku międzynarodowym itp. 
Willem Molle [Molle 1998, 17-22] wskazuje cztery teoretyczne modele wyjaśniania pojęcia rozszerzenia WE/UE jako polityczno-gospodarczej struktury integracyjnej:

1. Optymalny obszar integracyjny. Jego teoretyczne podstawy wywodzą się $\mathrm{z}$ teorii optymalnego obszaru walutowego dotyczącej tego, jakie warunki powinny być spełnione, aby dana grupa państw mogła jak najlepiej funkcjonować jako unia walutowa. Analogicznie, w przypadku optymalnego obszaru integracyjnego próbuje się wskazać warunki, jakie powinny spełniać państwa należące do danego ugrupowania integracyjnego na każdym etapie zaawansowania tej integracji. W efekcie państwa, które „osiągnęły między sobą pewien stopień wymiany i wykazują pewien stopień konwergencji polityki, winny uczestniczyć w integracji, podczas gdy kraje, które nie spełniają tych kryteriów, powinny być wykluczone z uczestnictwa" [Molle 2000, 531]. Według Molle'a warunkami tymi są: na etapie strefy wolnego handlu - „wysoki poziom wymiany towarów i usług”, „równość struktury produkcji” i „równość ładu gospodarczego”; na etapie wspólnego rynku - „równość na rynkach pracy i kapitału (ceny i dostępność)", „swoboda przemieszczania się (migracja i inwestycje)" oraz „konwergencja polityki (np. w dziedzinie podatków)”; na etapie unii gospodarczej - „efektywna koordynacja”, ,porównywalność instytucji” oraz ,płatności transferowe”, zaś na etapie unii walutowej - „stabilność kursów walutowych” oraz „,podobieństwo wstrząsów zewnętrznych” [Molle 2000, 532].

Jednak jak pisze sam W. Molle, zastosowanie tej teorii w praktyce jest trudne. Po pierwsze dlatego, że brak jest empirycznych podstaw do tego, aby precyzyjnie skwantyfikować wymienione kryteria. Jeśli np. ustalić minimalną wymianę handlową lub przepływ siły roboczej na niskim poziomie, to wiele państw mogłoby uczestniczyć w procesie integracji; jeśli natomiast poziom owych kryteriów byłby wysoki, to oczywiście liczba potencjalnych uczestników procesu integracji zostałaby ograniczona. Po drugie, w sytuacji, w której mamy kilka kryteriów członkostwa w procesie integracji na danym etapie, problemem jest to, jaką wagę przypiszemy każdemu z tych kryteriów. Poza tym trudno o dowody empiryczne na decydujące znaczenie tych kryteriów, jeśli spojrzeć na proces integracji w perspektywie dynamicznej - chodzi o to, że w przeszłości przyjmowano do WE państwa, które na początku nie w pełni spełniały kryteria optymalnego obszaru integracyjnego [Molle 1998, 18].

2. Analiza korzyści i kosztów. Decyzja o przystąpieniu danego państwa do ugrupowania integracyjnego (UE) jest konsekwencją analizy korzyści i kosztów wynikających z akcesji dla tego państwa oraz dla państw członkowskich UE. Problemem jest tutaj jednak przede wszystkim to, że trudno jest uchwycić z góry wszystkie gospodarcze następstwa w ujęciu dynamicznym, tzn. w dłuższej perspektywie czasu. Poza tym wyniki 
badań dotyczące gospodarczych następstw członkostwa w ugrupowaniu integracyjnym ex post nie potwierdzają badań przeprowadzanych ex ante, czyli przed akcesją danego państwa.

3. Teoria klubu. Decyzja o przystąpieniu, z jednej strony, oraz przyjęciu do ugrupowania integracyjnego nowego członka, $z$ drugiej, jest następstwem nie tylko analizy korzyści i kosztów, ale wynika także z innych przesłanek o charakterze dynamicznym (tzn. z uwzględnieniem zmian w czasie), wynikających z przynależności do danego ugrupowania. Chodzi tutaj o takie okoliczności jak np. ta, że państwa założycielskie ustanawiają reguły funkcjonowania danego ugrupowania, czy ta, kto w nim uczestniczy. Bardzo istotne w tym ujęciu jest to, że określone skutki pociąga za sobą nie tylko przystąpienie do danego ugrupowania integracyjnego, ale także pozostawanie poza nim. Na przykład korzyści, jakie osiągają podmioty (np. przedsiębiorstwa) z państw należących do UE, powodują, że często w gorszej sytuacji znajdują się podmioty z państw spoza UE. Następstwem jest dążenie kolejnych państw do przystąpienia do UE nie tylko po to, aby czerpać korzyści z członkostwa, ale także po to, aby uniknąć negatywnych skutków pozostawania poza ugrupowaniem integracyjnym. Jednocześnie kolejne akcesje stanowią swoistą presję wywieraną na państwa pozostające poza ugrupowaniem, co prowadzi do efektu domina.

4. Państwa postrzegane jak przedsiębiorstwa. W powyższych teoriach państwa były postrzegane jak „konsumenci”, którzy dążą do optymalizacji wartości swoich zasobów. W tej teorii państwa są traktowane jak ,„producenci”, którzy dążą do tego, aby zoptymalizować warunki swojego funkcjonowania w średnim i dłuższym okresie. Integracja państw jest tutaj wyjaśniana na podobieństwo fuzji przedsiębiorstw w coraz większe, wielonarodowe i produkujące coraz więcej towarów ugrupowania. Jednocześnie wzrost rozmiarów i pozycji rynkowej danej firmy powoduje, że podmioty rywalizujące znajdują się w trudniejszym położeniu, co z kolei skutkuje większą skłonnością do zgody na przejęcie przez większy podmiot.

W rzeczywistości nie sposób oczywiście wyjaśnić rozszerzenia WE/UE, wykorzystując tylko jeden z przedstawionych modeli. Poza tym uwaga koncentruje się w nich przede wszystkim na uwarunkowaniach gospodarczych, podczas gdy bardzo często kluczowe znaczenie mają czynniki polityczne, a uruchomienie procesu rozszerzenia (rozpoczęcie integracji z UE), jego przebieg i rezultaty są wypadkową bardzo wielu czynników politycznych i gospodarczych, dotyczących państwa kandydującego, WE/UE i otoczenia międzynarodowego.

Z punktu widzenia państw ubiegających się o członkostwo w WE/UE, przy uwzględnieniu wszystkich trudności związanych z procesem akcesji, z podjęciem wymaganych przez UE reform politycznych, gospodarczych, społecznych itp. czy z zaistnieniem pewnych negatywnych konsekwencji samego członkostwa, generalnie, jak wskazują dotychczasowe doświadczenia, z członkostwa w WE/ UE wynikają w przeważającej mierze raczej korzyści niż koszty. W wymiarze 
politycznym, jeśli uznać demokratyczny system polityczny za wartość, w państwach WE/UE demokracja, w porównaniu do momentu przystępowania do WE/ UE, raczej się utrwaliła i wzmocniła, niż osłabła. Szczególnie ma to znaczenie w państwach, w których nastąpiła transformacja ustrojowa, a więc w państwach Europy Południowej, Środkowej i Wschodniej. Członkostwo w WE/UE, jak pisze np. W. Sadurski, konsoliduje demokratyczne reformy ustrojowe i wzmacnia demokrację; jest sposobem na tendencje autorytarne i totalitarne, podnosi jakość administracji i wymiaru sprawiedliwości, sprzyja ochronie praw jednostki i rządom prawa [Sadurski 2012, 143]. Perspektywa przystąpienia do WE/UE wzmacnia konstytucjonalizm, szczególnie ochronę praw jednostki, w krajach kandydujących - nowo zdemokratyzowanych [Sadurski 2012]. Z kolei np. Mark Leonard nazywa wpływ UE na systemy polityczne państw kandydujących ,pasywną agresją” i, jego zdaniem, dla takich państw jak Turcja, Serbia czy Bośnia i Hercegowina jedyną rzeczą gorszą od ingerencji UE w ich systemy polityczne, od presji na przeprowadzanie reform itp. byłoby zatrzaśnięcie przed nimi drzwi do UE [Leonard 2005, 51]. Perspektywa członkostwa oraz członkostwo w UE wpływa także na zachowanie państwa w stosunkach z innymi państwami. Przystąpienie do UE oznacza również konieczność uregulowania konfliktów czy sporów z sąsiadami (co jest widoczne np. w odniesieniu do relacji turecko-grecko-cypryjskich) czy też współpracy z międzynarodowymi organami sądowymi (jak ma to miejsce w odniesieniu do państw byłej Jugosławii). W ten sposób UE wymusza podjęcie często bardzo trudnych problemów, które bez takiego czynnika motywującego jak perspektywa członkostwa w WE/UE być może nie zostałyby podjęte.

Także pod względem gospodarczym członkostwo w WE/UE wiąże się, mówiąc najogólniej, ze wzrostem poziomu zamożności i dobrobytu społeczeństw - wszystkie państwa, które przystąpiły do WE/UE, są dziś wyraźnie bogatsze niż w momencie akcesji. Oczywiście można w tym miejscu zastanowić się, jak wyglądałaby pod tym względem sytuacja jakiegoś państwa, gdyby nie przystąpiło ono do WE/UE, jednak UE ciągle pozostaje ugrupowaniem państw relatywnie stabilnych i zamożnych, a ta stabilność i zamożność jest atrakcyjna szczególnie dla krajów uboższych, osiągających dochód niższy niż średnia unijna. Argumentem na rzecz poglądu, że członkostwo w WE/UE przynosi więcej korzyści niż kosztów, jest także ten, że jak do tej pory żadne państwo członkowskie nie podjęło działań mających na celu opuszczenie WE/UE.

„Dla wielu sąsiadów UE jest czymś w rodzaju cudu obserwowanie państw demokratycznych dzielących suwerenność i działających razem dla wspólnego interesu bez konfliktu czy podboju" [Harris 2004, 113]. Oprócz minimalizowania ryzyka konfliktu pomiędzy państwami członkowskimi, polityka rozszerzania okazuje się, jak dotąd, najskuteczniejszym instrumentem polityki zewnętrznej WE/UE i umacniania pokoju i bezpieczeństwa w Europie - ,przez rozszerzenie unijnych norm, reguł, możliwości i ograniczeń dla państw kandydujących spowodowała i będzie powodować, że niestabilność i konflikt w szerszym regionie będą mniej prawdopodobne" [Missiroli, Quille 2004, 127-128]. Należy jednak 
zauważyć, że UE jest w stanie tak efektywnie oddziaływać dzięki rozszerzaniu swojego składu tylko na te państwa, które chcą do UE przystąpić. Polityka taka nie działa w chwili obecnej np. na Białoruś [Kubin 2011, Kubin 2013], a wcześniej, w latach 90. XX wieku, nie była skuteczna w odniesieniu do państw byłej Jugosławii (z wyjątkiem Słowenii).

Inna grupa korzyści z rozszerzania WE/UE dotyczy gospodarki. Dzięki przyłączeniu nowych rynków i eliminacji ceł i ograniczeń ilościowych następuje wzrost wymiany handlowej, dzięki zaś większej konkurencji i sprzyjaniu specjalizacji w procesie produkcji integracja prowadzi do efektywniejszej alokacji zasobów i wzrostu wydajności produkcji. Rozwój terytorialny WE/UE wiąże się z większymi możliwościami ekspansji gospodarczej firm z krajów już do UE należących, którym łatwiej jest handlować czy podejmować inwestycje w państwach bezpieczniejszych i stabilniejszych, gdzie znaczna część prawodawstwa dotyczącego prowadzenia działalności gospodarczej jest zbliżona albo identyczna jak w innych państwach członkowskich.

Obok analizy korzyści i kosztów wynikających z rozszerzenia czy też przystąpienia do UE, innym podejściem wyjaśniającym rozwój terytorialny WE/UE jest pogląd, zgodnie z którym integracja europejska jest procesem quasi-naturalnym, napędzanym wspólnymi wartościami, a dążenie do rozszerzenia wynika nie z kalkulacji korzyści i kosztów, ale przede wszystkim z tego, w jakim stopniu państwa kandydujące podzielają wspólne wartości i normy [Schneider 2009, 3-4].

Polityka rozszerzenia UE jest kontynuowana. W lipcu 2014 roku, używając unijnego żargonu, UE ,oferuje perspektywę członkostwa” ośmiu państwom: Turcji, Islandii, Albanii oraz pozostałym państwom Bałkanów Zachodnich, które jeszcze do UE nie należą. Spośród tych ośmiu państw oficjalny status kandydata ma pięć, a negocjacje rozpoczęły się z czterema z nich. Relacje, które mogą prowadzić do stowarzyszenia z UE lub nawet członkostwa w tej organizacji międzynarodowej, nawiązało z Unią także pięć państw - byłych republik związkowych ZSRR: Ukraina, Mołdawia, Armenia, Azerbejdżan i Gruzja. Należy zauważyć, że stopień zaawansowania relacji z UE każdego spośród tych trzynastu państw jest inny - od Kosowa, nieuznawanego nawet przez wszystkie państwa Unii, czy Armenii, która zakończyła negocjacje umowy stowarzyszeniowej, ale obecnie (2014 rok) deklaruje chęć przystąpienia do unii celnej Rosji, Białorusi i Kazachstanu - do Turcji, prowadzącej negocjacje akcesyjne już niemal dekadę [Kubin 2008], czy Islandii, której negocjacje z UE postępowały bardzo szybko, ale zostały zawieszone w 2013 roku po zmianie rządu w tym państwie. Syntetycznie stosunki UE z potencjalnymi państwami członkowskimi przedstawiono w tabeli 1 .

Tak jak bardzo zróżnicowany jest stan zaawansowania relacji potencjalnych nowych państw członkowskich z UE, tak też znajdują się one na bardzo różnych poziomach rozwoju społeczno-gospodarczego. Wybrane wskaźniki zawarto w tabeli 2.

Jak wspomniano, Rada Europejska w Kopenhadze w czerwcu 1993 roku, oprócz sformułowania warunków członkostwa w UE dotyczących państw kandydujących, zastrzegła, że każde nowe członkostwo będzie uzależnione od zdolności 
Tabela 1. Stosunki UE z potencjalnymi państwami członkowskimi (stan na lipiec 2014)

\begin{tabular}{|l|c|c|c|c|c|}
\hline \multicolumn{1}{|c|}{ Państwo } & $\begin{array}{c}\text { Układ stowa- } \\
\text { rzyszeniowy } \\
\text { podpisanie }\end{array}$ & $\begin{array}{c}\text { Układ stowa- } \\
\text { rzyszeniowy - } \\
\text { wejście w życie }\end{array}$ & $\begin{array}{c}\text { Wniosek } \\
\text { o czlonkostwo } \\
\text { w UE (WE) }\end{array}$ & $\begin{array}{c}\text { Status pań- } \\
\text { stwa kandy- } \\
\text { dującego }\end{array}$ & $\begin{array}{c}\text { Rozpoczęcie } \\
\text { negocjacji } \\
\text { akcesyjnych }\end{array}$ \\
\hline Turcja & 1963 & 1964 & 1987 & 1999 & 2005 \\
\hline Islandia & - & $-{ }^{-}$ & 2009 & 2010 & 2010 \\
\hline Czarnogóra & 2007 & $2010^{2}$ & 2008 & 2010 & 2012 \\
\hline Serbia & 2008 & 2013 & 2009 & 2012 & 2014 \\
\hline Macedonia & 2001 & $2004^{3}$ & 2004 & 2005 & -4 \\
\hline Albania & 2006 & $2009^{5}$ & 2009 & - & - \\
\hline $\begin{array}{l}\text { Bośnia } \\
\text { i Hercegowina }\end{array}$ & 2008 & -6 & - & - & - \\
\hline Kosowo & $--^{7}$ & - & - & - & - \\
\hline Armenia & -8 & - & - & - & - \\
\hline Azerbejdżan & $-9^{8}$ & - & - & - & - \\
\hline Gruzja & $2014^{10}$ & - & - & - & - \\
\hline Mołdawia & $2014^{11}$ & -12 & - & - & - \\
\hline Ukraina & $2014^{13}$ & - & - & - & - \\
\hline I & & & & - & - \\
\hline
\end{tabular}

${ }^{1}$ Islandia od 1973 r. należała do strefy wolnego handlu z państwami WE a od 1994 r. należy do Europejskiego Obszaru Gospodarczego.

${ }^{2}$ Układ o stosunkach handlowych UE-Czarnogóra wszedł w życie w 2008 r.

${ }^{3}$ Układ o stosunkach handlowych UE-Macedonia wszedł w życie w $2001 \mathrm{r}$.

${ }^{4}$ Komisja Europejska rekomendowała rozpoczęcie negocjacji akcesyjnych UE-Macedonia w 2009 r.

${ }^{5}$ Porozumienie tymczasowe (ang. Interim Agreement) UE-Albania dotyczące handlu weszło w życie w 2006 r.

${ }^{6}$ Układ stowarzyszeniowy został ratyfikowany, ale nie wszedł $\mathrm{w}$ życie. Porozumienie tymczasowe (ang. Interim Agreement) UE-Bośnia i Hercegowina dotyczące handlu weszło w życie w 2008 r.

${ }^{7}$ W 2012 r. Komisja Europejska opublikowała studium wykonalności dotyczące porozumienia o stowarzyszeniu i stabilizacji pomiędzy UE a Kosowem.

${ }^{8}$ Negocjacje umowy stowarzyszeniowej Armenii z UE zakończyły się w lipcu 2013 r. Ze względu na deklaracje Armenii o zamiarze przystąpienia do unii celnej Rosji, Białorusi i Kazachstanu umowa ta nie została podpisana. Podstawą relacji UE z Armenią jest umowa o partnerstwie i współpracy, która weszła w życie w 1999 r.

${ }^{9}$ Negocjacje umowy stowarzyszeniowej Azerbejdżanu z UE zaczęły się w 2010 r. Podstawą relacji UE z Azerbejdżanem jest umowa o partnerstwie i współpracy, która weszła w życie w 1999 r.

${ }^{10}$ Umowa stowarzyszeniowa Gruzji z UE została parafowana w 2013 r., a podpisana w czerwcu 2014 r. Umowa o partnerstwie i współpracy Gruzji z UE weszła w życie w 1999 r.

${ }^{11}$ Umowa stowarzyszeniowa Mołdawii z UE została parafowana w 2013 r., a podpisana w czerwcu 2014 r. Umowa o partnerstwie i współpracy Mołdawii z UE weszła w życie w 1998 r.

${ }^{12}$ Mołdawia ratyfikowała umowę stowarzyszeniową w lipcu 2014 r. Część postanowień tej umowy, w tym dotyczących strefy wolnego handlu (ang. Deep and Comprehensive Free Trade Area), ma tymczasowo obowiązywać od 1 września 2014 r.

${ }^{13}$ Umowa stowarzyszeniowa Ukrainy z UE została parafowana w 2012 r. W marcu 2014 r. podpisana została polityczna część umowy stowarzyszeniowej, a w czerwcu 2014 r. jej pozostałe części. Umowa o partnerstwie i współpracy Ukrainy z UE weszła w życie w 1998 r.

Źródło: Opracowanie własne na podstawie informacji na stronach Komisji Europejskiej (odczyt: 20.08.2014): http://ec.europa.eu/enlargement/index_en.htm; http://eeas.europa.eu/enp/index_en.htm. 
Unii do przyjęcia nowych członków. Tak ogólne sformułowanie stanowiło swoiste formalne uzasadnienie ewentualnego odwlekania przyjmowania nowych państw w sytuacji, w której spełniłyby one postawione im warunki a jednocześnie gdyby z jakichś powodów państwa już do UE należące chciały rozszerzenie odsunąć w czasie. Najogólniej, powody takiej polityki mogą być wynikiem sytuacji wewnętrznej w jakimś państwie UE (poglądy na rozszerzenie rządzących partii i/lub polityków, sytuacja gospodarcza, niechęć wobec rozszerzenia mieszkańców danego państwa), a także relacji dwustronnych państwa kandydującego z państwem członkowskim [Żornaczuk 2011, 54] albo mogą dotyczyć UE jako organizacji międzynarodowej. Dochodzimy w tym miejscu do jednego z najistotniejszych problemów związanych z polityką rozszerzenia UE (WE), a mianowicie wpływu tego rozszerzenia na funkcjonowanie UE i zachowanie dotychczasowych efektów procesu integracji czy też, innymi słowy, problemu związku poszerzenia UE (WE) z pogłębieniem integracji.

Tabela 2. Wybrane dane dotyczące potencjalnych państw członkowskich UE

\begin{tabular}{|c|c|c|c|c|c|c|c|c|}
\hline \multirow{2}{*}{$\begin{array}{l}\text { Wielkość } \\
\text { Państwo }\end{array}$} & \multirow[b]{2}{*}{$\begin{array}{l}\text { Lud- } \\
\text { ność } \\
(\mathrm{mln}, \\
2012)\end{array}$} & \multicolumn{2}{|c|}{$\begin{array}{c}\text { Human } \\
\text { Development } \\
\text { Index }(2013)\end{array}$} & \multicolumn{2}{|c|}{$\begin{array}{c}\text { Produkt Krajowy } \\
\text { Brutto }\end{array}$} & \multirow{2}{*}{$\begin{array}{c}\text { PKB } \\
\text { (ogółem, } \\
\text { ceny } \\
\text { bieżące, } \\
\text { mld } \\
\text { euro, } \\
2012 \text { ) }\end{array}$} & \multirow{2}{*}{$\begin{array}{c}\text { Stopa } \\
\text { bezro- } \\
\text { bocia } \\
(\%, \\
2012)\end{array}$} & \multirow{2}{*}{$\begin{array}{c}\text { Zadłu- } \\
\text { żenie } \\
\text { publicz- } \\
\text { ne } \\
(\% \text { PKB, } \\
2012)\end{array}$} \\
\hline & & $\begin{array}{c}\text { miejsce } \\
\text { w świecie } \\
\text { (na } 187 \\
\text { państw) }\end{array}$ & $\begin{array}{c}\text { wartość } \\
\text { HDI }\end{array}$ & $\begin{array}{c}\text { per capita, } \\
\text { parytet siły } \\
\text { nabywczej, } \\
\text { UE }=100 \\
(2013)\end{array}$ & $\begin{array}{c}\text { per } \\
\text { capita, } \\
\text { euro, } \\
2012\end{array}$ & & & \\
\hline Turcja & 74,724 & 69 & 0,759 & 55 & 8223 & 614,46 & 8,2 & $39,14^{1}$ \\
\hline Islandia & 0,319 & 13 & 0,895 & 116 & 32948 & 10,57 & 6,0 & 91,73 \\
\hline Czarnogóra & 0,621 & 51 & 0,789 & 42 & 5385 & 3,34 & 19,7 & 50,91 \\
\hline Serbia & 7,216 & 77 & 0,745 & 36 & 4134 & 29,93 & 23,9 & 59,04 \\
\hline Macedonia & 2,059 & 84 & 0,732 & 35 & 3651 & 7,49 & 31,0 & 34,14 \\
\hline Albania & 2,815 & 95 & 0,716 & 30 & 3344 & 9,37 & 13,9 & 63,54 \\
\hline $\mathrm{BiH}$ & 3,836 & 86 & 0,731 & 29 & 3419 & 13,11 & 28,6 & 27,73 \\
\hline Kosowo & 1,815 & b.d. & b.d. & b.d. & $2650^{1}$ & $4,77^{1}$ & 35,1 & $5,31^{1}$ \\
\hline Armenia & 3,021 & 87 & 0,730 & b.d. & 2559 & 7,741 & 18,5 & 44,11 \\
\hline Azerbejdżan & 9,235 & 76 & 0,747 & b.d. & 5823 & 53,439 & 5,4 & 8,80 \\
\hline Gruzja & 4,497 & 79 & 0,744 & b.d. & 2737 & 12,310 & 15,0 & 31,68 \\
\hline Mołdawia & 3,559 & 114 & 0,663 & b.d. & 1586 & 5,645 & 5,6 & 24,40 \\
\hline Ukraina & 45,453 & 83 & 0,734 & b.d. & 3018 & 137,184 & 7,7 & 36,60 \\
\hline
\end{tabular}

Źródło: Opracowanie własne na podstawie (odczyt: 21.08.2014): United Nations Development Programme: 2014 Human Development Report,http://hdr.undp.org/en/2014-report/download; Eurostat: http://epp.eurostat. ec.europa.eu/tgm/table.do?tab=table \&init=1\&plugin=1\&language $=$ en \&pcode $=$ tec 00114

http://epp.eurostat.ec.europa.eu/portal/page/portal/european_neighbourhood_policy/enp_east/data/database http://epp.eurostat.ec.europa.eu/portal/page/portal/enlargement_countries/data/database;The World Bank: http://data.worldbank.org/indicator/SL.UEM.TOTL.ZS. 
Jak się wskazuje, pomiędzy poszerzeniem a pogłębieniem może dochodzić do konfliktów. Po pierwsze, chodzi o funkcjonowanie instytucji UE i, w perspektywie krótkoterminowej, swoiste przesunięcie energii i uwagi z pogłębienia na negocjacje dotyczące przyjęcia nowych państw. Natomiast w dłuższym okresie poszerzenie może negatywnie wpływać na codzienne funkcjonowanie instytucji. Po drugie, poszerzenie może wpłynąć na funkcjonowanie niektórych polityk UE. Przyjmowanie nowych państw, zwłaszcza o odmiennym od zachodnioeuropejskiego dziedzictwie historycznym, różnych uwarunkowaniach politycznych, niższym poziomie rozwoju społeczno-gospodarczego itp., oznacza nadanie UE „nowej jakości politycznej” [Milczarek 2014, 13]. Po trzecie, nowe państwa członkowskie mogą być politycznie zróżnicowane i mogą kwestionować dalsze pogłębianie procesu integracji [Croft, Redmond, Wyn Rees, Weber 1999, 79].

Jak do tej pory, w historii integracji w ramach UE (WE) każdemu rozszerzeniu towarzyszyły nie tylko konieczne dostosowania w zakresie funkcjonowania instytucji, ale także działania na rzecz pogłębienia integracji. Można chyba nawet postawić tezę, że perspektywy rozszerzenia UE (WE) wykorzystywane były jako swoisty pretekst do tego, aby pogłębić integrację. Pierwszemu rozszerzeniu towarzyszyło podjęcie działań mających na celu wprowadzenie unii walutowej w oparciu o raport Pierre'a Wernera, a także rozwój polityki regionalnej i rybołówstwa. $Z$ drugim rozszerzeniem związane są bezpośrednie wybory do PE i początek funkcjonowania Europejskiego Systemu Walutowego. Trzecie rozszerzenie nastąpiło w tym samym czasie, w którym wypracowany został Jednolity Akt Europejski, z jego programem dokończenia budowy wspólnego rynku, wzmocnienia polityki społecznej, wzrostu kompetencji PE czy współpracy w sferze polityki zagranicznej (Europejska Współpraca Polityczna). Traktat z Maastricht, na mocy którego utworzono UE, a w jej ramach m.in. Unię Gospodarczą i Walutową, Wspólną Politykę Zagraniczną i Bezpieczeństwa oraz ustanowiono współpracę w dziedzinie wymiaru sprawiedliwości i spraw wewnętrznych, przyjmowany był nie tylko z myślą o czwartym rozszerzeniu, ale także z perspektywą akcesji kilkunastu państw Europy Środkowej i Wschodniej. W pełni przygotować UE na tak duże rozszerzenie miały: Traktat z Amsterdamu, Traktat z Nicei oraz Traktat ustanawiający Konstytucję dla Europy. W kontekście obaw o spowolnienie procesu integracji z powodu poszerzenia UE należy w tym miejscu wspomnieć o wprowadzonych w TA postanowieniach o możliwości nałożenia sankcji na państwo naruszające zasady UE oraz ustanowieniu przez grupę państw UE wzmocnionej współpracy [Kubin 2006, Kubin 2010, Kubin 2012]. W. Sadurski pisze też, że rozszerzenie jest bardzo istotnym czynnikiem, który sprzyja procesowi konstytucjonalizacji UE i wskazuje w tym kontekście na Kartę Praw Podstawowych [Sadurski 2012, 54].

Trzecią grupą podmiotów mających decydujący wpływ na proces rozszerzenia są państwa członkowskie UE. Jak zauważa np. Ch. J. Schneider, mają one różne interesy i mogą odnosić różne korzyści i koszty z przyjmowania nowych państw, a sprzeciw jednego państwa członkowskiego może zablokować rozszerzenie [Sch- 
neider 2009, 4]. Autorka ta zwraca uwagę na koszty wynikające z innej dystrybucji środków finansowych po rozszerzeniu oraz na to, że kraje członkowskie bezpośrednio graniczące z państwami kandydującymi bardziej wspierają rozszerzenie niż kraje, które takich bezpośrednich granic nie mają [Schneider 2009, 42-44].

Czynnikiem dotyczącym zarówno państw kandydujących, jak i członkowskich i mającym duże znaczenie dla procesu rozszerzenia jest nastawienie opinii publicznej do, odpowiednio, przystąpienia do UE lub przyjęcia nowych państw do Unii. Biorąc pod uwagę to, że w państwach kandydujących najczęściej ratyfikacja traktatu akcesyjnego poprzedzana jest referendum, należy podkreślić, iż pozytywny stosunek opinii publicznej do wejścia do UE jest istotniejszy niż przychylność dla rozszerzenia w państwach członkowskich, w których o ratyfikacji traktatów akcesyjnych decydują parlamenty i/lub głowy państw. Możliwe jest więc rozszerzenie UE przy negatywnym nastawieniu do tego mieszkańców danego państwa członkowskiego, chociaż, z oczywistych względów, rządzący wolą takich decyzji unikać. Stosunek opinii publicznej w krajach członkowskich może zatem mieć wpływ na decyzje o rozpoczęciu negocjacji czy tempie ich prowadzenia - tak, aby np. odłożyć w czasie ,niewygodną” decyzję lub aby zablokować/zahamować proces rozszerzenia na etapie wcześniejszym niż ratyfikacja wynegocjowanego traktatu akcesyjnego. W dwóch kolejnych tabelach przedstawiono odpowiedzi na pytania dotyczące rozszerzenia UE (badanie zostało przeprowadzone wiosną 2014 roku). W tabeli 3 pokazano nastawienie mieszkańców państw UE do rozszerzenia Unii.

Tabela 3. Stosunek do rozszerzenia UE mieszkańców państw Unii (dane w \%)

\begin{tabular}{|l|c|c|c|l|c|c|c|}
\hline \multicolumn{1}{|c|}{ Państwo } & Za & Przeciw & Nie wiem & \multicolumn{1}{|c|}{ Państwo } & Za & Przeciw & Nie wiem \\
\hline Belgia & 33 & 62 & 5 & Litwa & 65 & 19 & 16 \\
\hline Bułgaria & 53 & 21 & 26 & Luksemburg & 26 & 65 & 9 \\
\hline Czechy & 44 & 46 & 10 & Węgry & 58 & 33 & 9 \\
\hline Dania & 40 & 52 & 8 & Malta & 61 & 24 & 15 \\
\hline Niemcy & 21 & 71 & 8 & Holandia & 32 & 62 & 6 \\
\hline Estonia & 48 & 37 & 15 & Austria & 25 & 67 & 8 \\
\hline Irlandia & 40 & 47 & 13 & Polska & 55 & 23 & 22 \\
\hline Grecja & 44 & 50 & 6 & Portugalia & 42 & 44 & 14 \\
\hline Hiszpania & 49 & 28 & 23 & Rumunia & 70 & 16 & 14 \\
\hline Francja & 23 & 69 & 8 & Słowenia & 58 & 34 & 8 \\
\hline Chorwacja & 64 & 25 & 11 & Słowacja & 49 & 41 & 10 \\
\hline Włochy & 33 & 44 & 23 & Finlandia & 28 & 63 & 9 \\
\hline Cypr & 39 & 47 & 14 & Szwecja & 48 & 42 & 10 \\
\hline Łotwa & 49 & 35 & 16 & W. Brytania & 32 & 52 & 16 \\
\hline
\end{tabular}

Źródło: Standard Eurobarometer 81, pytanie QA17.3, http://ec.europa.eu/public_opinion/archives/eb/eb81/ eb81_anx_en.pdf (odczyt: 30.08.2014).

W tabeli 4 natomiast zawarto wyniki odpowiedzi na pytania pokazujące stosunek do członkostwa w UE mieszkańców pięciu państw, które obecnie mają oficjalny status kandydata do UE. 
Tabela 4. Ocena mieszkańców wybranych państw kandydujących ich członkostwa w UE (dane $\mathrm{w} \%)$

\begin{tabular}{|l|c|c|c|c|c|c|c|}
\hline \multirow{3}{*}{ Państwo } & \multicolumn{3}{|c|}{ Członkostwo Twojego kraju w UE } & \multicolumn{3}{c|}{$\begin{array}{c}\text { Biorąc wszystko pod uwagę, } \\
\text { Twój kraj na czlonkostwie w UE... }\end{array}$} \\
\cline { 2 - 8 } & dobre & złe & ani dobre, ani złe & nie wiem & skorzysta & nie skorzysta & nie wiem \\
\hline Turcja & 38 & 33 & 27 & 2 & 50 & 45 & 5 \\
\hline Macedonia & 51 & 18 & 30 & 1 & 66 & 29 & 5 \\
\hline Islandia & 36 & 29 & 27 & 8 & 46 & 42 & 12 \\
\hline Czarnogóra & 51 & 17 & 31 & 1 & 65 & 30 & 5 \\
\hline Serbia & 40 & 19 & 38 & 3 & 57 & 32 & 11 \\
\hline
\end{tabular}

Źródło: Standard Eurobarometer 81, pytanie QA7 i QA8, http://ec.europa.eu/public_opinion/archives/eb/eb81/eb81_anx_en.pdf (odczyt: 30.08.2014).

\section{PODSUMOWANIE}

Jest oczywiste, że rozszerzenie UE jest „łatwiejsze” w odniesieniu do państw o stabilnym i utrwalonym ustroju demokratycznym i gospodarce wolnorynkowej, silnych i sprawnych instytucjach publicznych, o wysokim poziomie zamożności i rozwoju społeczno-gospodarczego, podobnej do państw UE strukturze gospodarczej, państw, które mają dobre stosunki z sąsiadami (a przynajmniej nie mają z nimi żadnych konfliktów), podobnych pod względem kulturowym, raczej mniejszych pod względem powierzchni i liczby ludności (mniejsze ewentualne koszty finansowe rozszerzenia). Spośród państw będących aktualnie potencjalnymi nowymi członkami UE takim krajem jest tylko Islandia. Można więc powiedzieć, że „łatwe” rozszerzenia UE już się skończyły.

Dwoma czynnikami, które mają obecnie (2014 rok) decydujący wpływ na kontynuację procesu rozszerzenia UE, są wydarzenia na Ukrainie oraz trwający od kilku lat kryzys gospodarczy. Kryzys i jego następstwa od paru lat są głównym przedmiotem zainteresowania instytucji UE i jej państw członkowskich; inne problemy zeszły na dalszy plan. W kontekście rozszerzenia ma to znaczenie także takie, że, jak można argumentować, konieczne jest najpierw zreformowanie UE i jej wzmocnienie, aby można było przyjmować nowe państwa. Kryzys spowodował także niechęć do ponoszenia kosztów finansowych kolejnych akcesji i ostrożność przed przyjmowaniem państw, które w przyszłości mogłyby być źródłem kłopotów gospodarczych i finansowych, jak np. Grecja czy Cypr. Poza tym toczona kryzysem UE stała się chyba nieco mniej atrakcyjna.

Z kolei wydarzenia na Ukrainie w kontekście rozszerzenia UE będą skutkować m.in. jeszcze większą ostrożnością i niechęcią UE do przyjmowania państw, których akcesja mogłaby oznaczać ryzyko wciągnięcia Unii w jakieś konflikty zbrojne. Na przykład minister spraw zagranicznych Niemiec Frank-Walter Steinmeier na pytanie o to, czy widzi kiedyś Ukrainę w NATO i UE, odpowiedział: „Ukrainy na drodze do NATO nie widzę. A jeśli chodzi o rozszerzenie UE, to na razie koncentrujemy się na zachodnich Bałkanach. To wystarczająco trudne 
wyzwanie. Co będzie później? Nie wiem" [Steinmeier 2014]. Należy w tym miejscu podkreślić, że znaczenie rozszerzenia dla problematyki bezpieczeństwa UE jest tym większe, iż na mocy zmian zawartych w Traktacie z Lizbony państwa członkowskie UE zobowiązały się do wzajemnej pomocy w przypadku agresji zbrojnej na terytorium jednego z nich. Stosowne postanowienie zawarte jest $\mathrm{w}$ art. 42 ust. 7 TUE: „w przypadku gdy jakiekolwiek państwo członkowskie stanie się ofiarą napaści zbrojnej na jego terytorium, pozostałe państwa członkowskie mają w stosunku do niego obowiązek udzielenia pomocy i wsparcia przy zastosowaniu wszelkich dostępnych im środków, zgodnie z artykułem 51 Karty Narodów Zjednoczonych. Nie ma to wpływu na szczególny charakter polityki bezpieczeństwa i obrony niektórych państw członkowskich. Zobowiązania i współpraca w tej dziedzinie pozostają zgodne ze zobowiązaniami zaciągniętymi w ramach Organizacji Traktatu Północnoatlantyckiego, która dla państw będących jej członkami pozostaje podstawą ich zbiorowej obrony i forum dla jej wykonywania".

Poza tym, jak słusznie zauważa np. Dariusz Milczarek, w ogóle idea kontynuowania rozszerzenia UE na Wschód „budzi coraz większe wątpliwości”. Oprócz kryzysu na Ukrainie, autor ten wskazuje, że przyczyniają się do tego także m.in. problemy, szczególnie w Rumunii i Bułgarii, z korupcją i zorganizowaną przestępczością, tendencje antydemokratyczne i nacjonalistyczne na Węgrzech czy wzrost populizmu w życiu politycznym, m.in. w Polsce [Milczarek 2014, 10]. Tomasz Żornaczuk także pisze o „negatywnych doświadczeniach” UE, wynikających z przyjęcia Rumunii i Bułgarii [Żornaczuk 2011, 56]. Jednocześnie jednak, zdaniem tego autora, jeżeli się podejdzie do kwestii rozszerzenia UE na Wschód „Z czysto pragmatycznego punktu widzenia [...], wszystko zdaje się wskazywać, jeśli nie konieczność, to przynajmniej sensowność kontynuowania" tego procesu [Milczarek 2014, 24].

Biorąc wskazane wyżej uwarunkowania pod uwagę, należy stwierdzić, iż proces dalszego rozszerzania UE nie będzie przebiegał szybko i bez problemów. W przypadku niektórych spośród wskazanych wyżej państw - potencjalnych kandydatów do UE - perspektywa ich wejścia do UE może być liczona, w najlepszym razie, w dekadach. Być może jedynym możliwym do przyjęcia dla UE rozwiązaniem będzie jakaś formuła tzw. alternatywnych koncepcji dla pełnego członkostwa, jak np. wymieniane przez A. Szymańskiego ,uprzywilejowane partnerstwo”, ,rozszerzone członkostwo stowarzyszone”, ,stopniowe członkostwo”, Unia Śródziemnomorska czy Europejska Polityka Sąsiedztwa Plus [Szymański $2012,48]$. Coraz wyraźniej zarysowują się także zróżnicowania, jeśli chodzi o poziom integracji pomiędzy obecnymi państwami członkowskimi UE, zaś głównym kryterium tych różnic jest członkostwo lub pozostawanie poza strefą euro. 


\section{WYKAZ PIŚMIENNICTWA}

1. Croft S., Redmond J., Wyn Rees G., Weber M., 1999, The enlargement of Europe, Manchester University Press.

2. European Council, 1993, Conclusions of the Presidency, Copenhagen, 21-22 June 1993, http:// www.consilium.europa.eu/uedocs/cms_data/docs/pressdata/en/ec/72921.pdf.

3. European Council, 1995, Conclusions of the Presidency, Madrid, 15 and 16 December 1995, http://www.consilium.europa.eu/uedocs/cms_data/docs/pressdata/en/ec/00400-C.EN5.htm.

4. European Council, 1999, Presidency Conclusions, Helsinki, 10 and 11 December 1999, http:// www.consilium.europa.eu/uedocs/cms_data/docs/pressdata/en/ec/ACFA4C.htm.

5. European Council, 2000a, Presidency Conclusions, Santa Maria de Feira, 19 and 20 June 2000, http://www.consilium.europa.eu/uedocs/cms_data/docs/pressdata/en/ec/00200-r1.en0.htm.

6. European Council, 2000b, Presidency Conclusions, Nice, 7, 8 and 9 December 2000. http:// www.consilium.europa.eu/uedocs/cms_data/docs/pressdata/en/ec/00400-r1.\%20ann.en0.htm.

7. European Council, 2001a, Presidency Conclusions, Göteborg, 15 and 16 June 2001. http://www. consilium.europa.eu/uedocs/cms_data/docs/pressdata/en/ec/00200-r1.en1.pdf.

8. European Council, 2001b, Presidency Conclusions, Laeken, 14 and 15 December 2001. http:// www.consilium.europa.eu/uedocs/cms_data/docs/pressdata/en/ec/68827.pdf.

9. European Council, 2002, Presidency Conclusions, Seville, 21 and 22 June 2002. http://www. consilium.europa.eu/uedocs/cms_data/docs/pressdata/en/ec/72638.pdf.

10. Harris G., 2004,The wider Europe, [w:] The future of Europe. Integration and enlargement, ed. F. Cameron, Routledge, London-New York.

11. Kubin T., 2006, Zdynamizowanie procesu integracji czy członkostwo różnych kategorii? Zagadnienie wzmocnionej współpracy w Unii Europejskiej, [w:] Unia Europejska i Polska wobec dylematów integracyjnych na początku XXI wieku, red. M. Stolarczyk, Wydawnictwo Adam Marszałek, Toruń.

12. Kubin T., 2008, Zagadnienie członkostwa Turcji w Unii Europejskiej, Stosunki Międzynarodowe, nr 3-4 (t. 38)/2008.

13. Kubin T., 2010, Wzmocniona współpraca państw Unii Europejskiej w świetle Traktatu z Lizbony, Rocznik Integracji Europejskiej, nr 4.

14. Kubin T., 2011, The EU Policy Towards Belarus in the Context of the Presidential Elections on 19 December 2010, Athenaeum. Polskie Studia Politologiczne, vol. 30.

15. Kubin T., 2012, Kryzys gospodarczy i zadłużeniowy a zróżnicowanie integracji w Unii Europejskiej, Studia Europejskie, nr 3 (63).

16. Kubin T., 2013, W poszukiwaniu rezultatów... Polityka Unii Europejskiej wobec Białorusi, Studia Politicae Universitatis Silesiensis, t. 10.

17. Kubin T., 2013, Pokój jako cel i efekt procesu integracji europejskiej po II wojnie światowej, [w:] Śląsk - Polska - Europa - Świat, red. K. Miroszewski, M. Stolarczyk, Wydawnictwo Uniwersytetu Śląskiego, Katowice.

18. Leonard M., 2005, Why Europe will run the $21^{\text {st }}$ century, Fourth Estate, London-New York.

19. Milczarek D., 2014, Rozszerzenie Unii Europejskiej na Wschód - geneza, rezultaty, perpsektywy, Studia Europejskie, nr 1(69).

20. Missiroli A., Quille G., 2004, European security in flux, [w:] The future of Europe. Integration and enlargement, ed. F. Cameron, Routledge, London-New York.

21. Molle W., 1998, Explaining the dynamics of enlargement of the EU: a review of various approaches, [w:] EU adjustment to Eastern enlargement. Polish and European perspectiv,. eds. A. Zielińska-Głębocka, A. Stępniak, Wydawnictwo Uniwersytetu Gdańskieg, Gdańsk. 
22. Molle W., 2000, Ekonomika integracji europejskiej. Teoria, praktyka, polityka, Wydawnictwo Fundacja Gospodarcza, Gdańsk.

23. Sadurski W., 2012, Constitutionalism and the enlargement of Europe, Oxford University Press.

24. Schneider C. J., 2009, Conflict, negotiation and European Union enlargement, Cambridge University Press.

25. Steinmeier F-W., 2014, Rosja słono płaci za Ukrainę, rozmowa z Frankiem-Walterem Steinmeierem, Gazeta Wyborcza z 06.05.2014.

26. Szymański A., 2012, Rozszerzenie Unii Europejskiej. Współczesne uwarunkowania i perspektywy kontynuacji procesu, Oficyna Wydawnicza Aspra, Warszawa.

27. Traktat o Unii Europejskiej, 2010, Dziennik Urzędowy Unii Europejskiej C 83, 30.03.2010.

28. Żornaczuk T., 2011, Rozszerzenie Unii Europejskiej a prezydencja Polski w Radzie UE, Polski Przegląd Dyplomatyczny, nr 1(59).

\title{
THE CONTINUATION OF THE ENLARGEMENT PROCESS AS A CHALLENGE FOR THE EUROPEAN UNION
}

\begin{abstract}
The process of integration in Western Europe, undertaken since World War II, has proven a success. Additional countries have taken actions to join the European Communities, and the $\mathrm{EC} / \mathrm{EU}$ policy of enlargement has become one of its most important activities.

The purpose of the article is to identify and briefly analyse certain aspects, mainly theoretical, related to the continuation of EU enlargement and to identify the most significant factors that affect its future course. The main thesis of the study is that the continuation of EU enlargement will look significantly different in the future than in the past and that it will be a difficult and lengthy process. The research problem is to identify the causes of the change in the EU enlargement process, generally appraised as one of its most successful policies. To achieve this aim, theoretical models explaining EU enlargement and practical factors affecting the enlargement process are identified. To better understand the current circumstances influencing the EU enlargement process, the article includes information on the current state of EU relations with potential new member states, selected data on the socio-economic development of those countries, and public attitudes in the EU and some candidate states. The formal conditions that must be met by a candidate state are presented in the first part of the study. The summary contains the most important conclusions.
\end{abstract}

Key words: enlargement, the European Union 